DOI: 10.30842/ielcp230690152443

Luka Repanšek

(University of Ljubljana, Slovenija)

\title{
THE ACCENTUAL PROFILE OF VEDIC NOMINAL PARADIGMS
}

The contribution attempts to systematise the paradigmatic accentual behaviour of Vedic nominal stems $(\S 1)$ and seeks to provide diachronic reasoning behind the synchronic state of affairs, especially as regards any secondary contours in stably mobile paradigms (\$3) and the rise of immobility (§2).

Key words: Vedic, nominal morphology, accent, accentual paradigms.

\section{Л. Репаншек \\ (Люблянский университет, Словения)}

\section{Акцентные типы ведийских именных парадигм}

В статье предпринята попытка выявить закономерности в акцентуации ведийских именных основ. Рассматриваются случаи сохранения статических парадигм и расширение их числа, а также эволюция каждого из динамических типов. Автор формулирует правило, согласно которому «любая многосложная основа, по своему происхождению относящаяся к динамическим парадигмам, если она в сильных падежах имеет ударение на корне, утратившем аблаутные чередования, переходит в статические парадигмы».

Автор последовательно соотносит место ударения с словообразовательными особенностями. Например, ведийские формы композитов типа татпуруша сопоставляются с авестийскими, в том числе композиты со вторым элементом - $a(N) c-$.

Завершает статью экскурс, посвященный слову kan $y a n-$ 'девушка, девочка' (Nom. sg. kanìȳa, Acc. sg. kanyánām $\leftarrow *$ kanyànam < *kaníianam; в слабых падежах kanīn-) в (раннем) ведийском. Ожидалась бы гистеродинамическая парадигма: Nom. sg. *knni- $H_{3} \bar{e} n>$

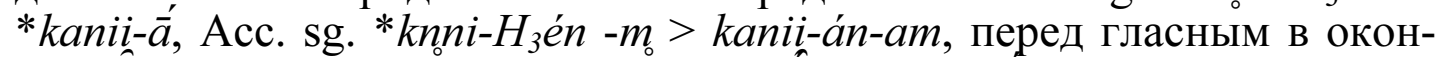
чании косвенных падежей * knni-H $H_{3}$ - $^{-}{ }^{*} k a n i n-$, но в ходе развития уже в ведийском языке слово перешло в стативную акцентную парадигму склонения.

Ключевые слова: ведийский язык, именная морфология, ударение, акцентно-аблаутные парадигмы, ведийск. kan yan- 'девушка, девочка'

$\S$ 1. Synchronically speaking, paradigm-bound accentual contour (AC) of any Vedic nominal declensional pattern can be said 
to belong to one of the following six patterns, two of which are immobile (columnar), and the rest (mostly marginally) mobile: ${ }^{1,2}$

\begin{tabular}{|l|l|l|l|}
\cline { 2 - 3 } \multicolumn{1}{c|}{} & \multicolumn{3}{|c|}{ acrocolumnar } \\
\cline { 2 - 4 } \multicolumn{1}{c|}{} & \multicolumn{2}{|c|}{$\mathrm{I}$} \\
\hline the strong stem $(\mathrm{S})$ & $\mathbf{R x}$ & $(\mathrm{Sx})$ & $\mathrm{T}$ \\
\hline the weak stem $(\mathrm{W})$ & $\mathbf{R x}$ & $(\mathrm{Sx})$ & $\mathrm{T}^{\mathrm{V}}$ \\
\hline the middle stem $(\mathrm{M})$ & $\mathbf{R x}$ & $(\mathrm{Sx})$ & $\mathrm{T}^{\mathrm{C}}$ \\
\hline
\end{tabular}

\begin{tabular}{|l|l|l|}
\hline \multicolumn{3}{|c|}{ mesocolumnar } \\
\hline \multicolumn{3}{|c|}{ II } \\
\hline $\mathbf{R x}$ & $\mathbf{S x}$ & $\mathbf{T}$ \\
\hline $\mathrm{Rx}$ & $\mathbf{S x}$ & $\mathbf{T}^{\mathrm{V}}$ \\
\hline $\mathrm{Rx}$ & $\mathbf{S x}$ & $\mathbf{T}^{\mathrm{C}}$ \\
\hline
\end{tabular}

\begin{tabular}{|l|l|}
\hline \multicolumn{2}{|c|}{ amphidynamic } \\
\hline \multicolumn{2}{|c|}{ III } \\
\hline $\mathbf{R x}$ & $\mathrm{T}$ \\
\hline $\mathrm{Rx}$ & $\mathbf{T}^{\mathrm{V}}$ \\
\hline $\mathrm{Rx}$ & $\mathbf{T}^{\mathrm{C}}$ \\
\hline
\end{tabular}

\begin{tabular}{|l|l|l|l|}
\cline { 2 - 3 } \multicolumn{1}{c|}{} & \multicolumn{3}{c|}{ proterodynamic } \\
\cline { 2 - 4 } \multicolumn{1}{c|}{} & \multicolumn{3}{|c|}{$\mathrm{IV}$} \\
\hline the strong stem $(\mathrm{S})$ & $\mathbf{R x}$ & $\mathrm{Sx}$ & $\mathrm{T}$ \\
\hline the weak stem $(\mathrm{W})$ & $\mathbf{R x}$ & $\mathbf{S x}$ & $\mathrm{T}^{\mathrm{V}}$ \\
\hline the middle stem $(\mathrm{M})$ & $\mathrm{Rx}$ & $\mathbf{S x}$ & $\mathrm{T}^{\mathrm{C}}$ \\
\hline
\end{tabular}

\begin{tabular}{|l|l|l|}
\hline \multicolumn{3}{|c|}{ hysterodynamic } \\
\hline \multicolumn{2}{|c|}{$\mathrm{V}$} \\
\hline $\mathrm{Rx}$ & $\mathbf{S x}$ & $\mathrm{T}$ \\
\hline $\mathrm{Rx}$ & $\mathrm{Sx}$ & $\mathbf{T}^{\mathrm{V}}$ \\
\hline $\mathrm{Rx}$ & $\mathbf{S x}$ & $\mathrm{T}^{\mathrm{C}}$ \\
\hline
\end{tabular}

\begin{tabular}{|l|l|l|}
\hline \multicolumn{3}{|c|}{ holodynamic } \\
\hline \multicolumn{3}{|c|}{$\mathrm{VI}$} \\
\hline $\mathbf{R x}$ & $\mathrm{Sx}$ & $\mathrm{T}$ \\
\hline $\mathrm{Rx}$ & $\mathrm{Sx}$ & $\mathbf{T}^{\mathrm{V}}$ \\
\hline $\mathrm{Rx}$ & $\mathbf{S x}$ & $\mathrm{T}^{\mathrm{C}}$ \\
\hline
\end{tabular}

\section{$\S$ 1.1.Membership}

\section{$\S$ 1.1.1. Immobile / columnar patterns}

\section{The acrocolumnar $A C$}

Inherited members:

a) Proto-Indo-European (PIE) barytone thematic (*CV́C-o-) stems (including *-e- $\mathrm{H}_{2}$ - feminatives);

b) The primarily acrostatic root-noun $\mathrm{S} g \bar{a} v-$, W gáv-, $\mathrm{M}$ gó-

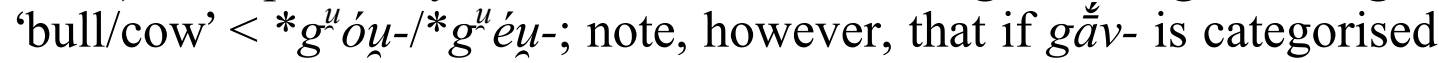
as a root noun, its immobility is in fact unexpected. There is no

\footnotetext{
${ }^{1}$ NB As will be noticed, the terminology for the mobile patterns is simply borrowed from the customary system used in Indo-European linguistics to describe the types of accentual curves relevant for the parent language. For the immobile patterns I have for the purposes of at least minimal terminological differentiation replaced the term static with columnar, which, however, amounts to the same thing as far as the curve itself (and only the curve) is concerned. Note that in Indo-European comparative linguistics these terms also imply the type of ablaut ( $e-, O$ - or zero-grade) that is automatically patterned with the respective accentual profile, which of course plays no such role in the case of the Vedic system, so that the terminology applied here (in as much as it overlaps with its concurrent use to describe IE paradigmatic classes, that is to say accent and ablaut paradigms) should be understood literally, i.e., referring to the type of accent movement only.

${ }^{2}$ First systematised in purely synchronic terms and for essentially pedagogical purposes in Repanšek 2017: 33.
} 
apparent reason why any root noun, regardless of whether it reflects an acrostatic or an amphidynamic PIE non-affixal deradical derivative, would fail to surface as mobile (if mobile in PIE) or secondarily mobilised (if acrostatic in PIE) in Vedic. The acrocolumnar curve of $g \stackrel{\underline{a}}{v}$ - cannot therefore be the direct result of its PIE heritage but rather it is its inherited immobility that helped to create the crucial link between the G/Abl. sg. form gós and the mesocolumnar paradigm of $u$-stems ${ }^{3}$, which - as far as the accentual pattern is concerned - this monosyllabic stem in all reality follows and as such effectively evades accentual mobilisation that affected the category of originally immobile monosyllabic root nouns (meaning those that were indeed interpretable as such on the synchronic level), cf. infra;

c) $C a ́ C$-an- neuters from PIE acrostatic neuter nasal stems *Có $\mathrm{C}-n-/{ }^{*} C e ́ C-n_{0}-{ }^{4}$;

d) The only two neuter heteroclites to escape the inner-Vedic restructuring via velar (and whenever dissimilated, virtually dental) excrescence in the NAsg., viz. áhar-láhn- 'day' $<*(H) a ́ d \zeta^{h} a r l$

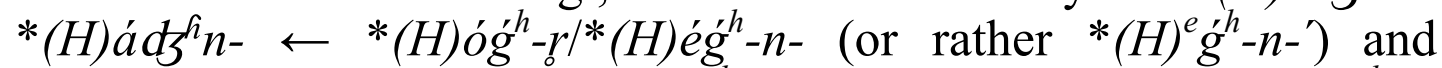

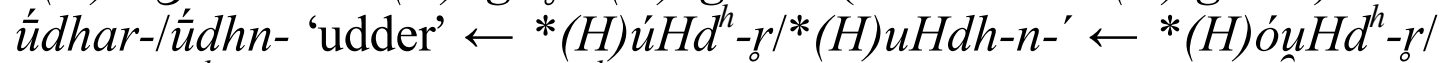
*(H)uHd ${ }^{h}-n$-' $^{*} \leftarrow$ * $(H)$ éuH $\left.H d^{h}-n-\right)$;

e) PIE sigmatic neuters ${ }^{*} C e ́ C$-os- $\sim{ }^{*} C e ́ C$-es- (including their compositional forms in exocentric compounds $\left.{ }^{\circ} \mathrm{CáC}-a s_{-}\right)^{5}$ and ${ }^{*} C e ́ C-u-s-$ simplexes, as well as jyótiș- 'radiance' as the only neuter -is-stem to escape secondary oxytonisation (see below) due to its being synchronically reinterpreted as a stem in -ti-;

f) The active present/aorist participle of immobile derivational bases (Narten-presents, sigmatic aorists, $a-(<* e-)$ reduplicated presents, the intensive) and dethematic participles of any barytone thematics;

Newcomers:

a) The root noun nár- 'man' < PIE $* H_{2}$ ner-, due to a combination of two innovations, viz. the introduction of a neoprevocalic stem nár- for expected $* n r-<{ }^{*} H_{2} n r$ - and subsequent levelling of the accent (with the exception of the Gpl. nar-ắm and its restructuring $n \bar{r} / \breve{r} n \bar{a} m$ ), and the fact that the noun was not

${ }^{3} \mathrm{Cf}$. Wackernagel/Debrunner 1954: $\S 6 \mathrm{~b} \beta$ for the same proposal.

${ }^{4}$ The only potential candidate in this group being nắman- 'name' (if from * $H_{1}$ nóm-no $)$, which, however, is ultimately ambiguous.

${ }^{5}$ For PIE ${ }^{\circ} \mathrm{C}(e) C$-és- with the accent position secondarily levelled in from the simplex. 
synchronically treated as a root noun but as a stem in $-r$ - and therefore expectedly kept the accent on what in this case happened to be also the first syllable even in the middle cases ( $n \dot{r}$ - as in, e.g., pi-tŕ- etc., for which see below);

b) The otherwise mobile monosyllabic root nouns (if looked at as separate entities, but otherwise, i.e., from the point of view of the entire nexus, mesocolumnar) as second members of compounds and, by association, any synchronically polysyllabic root nouns (such as reduplicated formations and opaque compounds $)^{6}$;

c) The present participle active of $i / u$-reduplicated presents by levelling the pattern with the inherited state of affairs in the inherently immobile $a-(<* e-)$ reduplicated presents (since the latter group were accented on the reduplication syllable);

d) Deadverbial (and marginally desubstantival or deadjectival) adjectives in $-a(N) c$ - if the derivational base was structurally either (C) $V^{\prime} C a(-)$ or, alternatively, ended in $-i$ - or $-u$ - within a monosyllabic structure (with the notable but expected exception of $s u^{-}$, for which see below);

e) The inherently immobile (!) possessive (relational) adjectives in $-v /$ mant-, except when the derivational base was a disyllabic oxytone -í-, -ú-, -(á)r- or -án- stem (see $\S 3$ for particulars);

f) All polysyllabic derived mobile stems with inherited original root-accentuation in the strong forms and concomitant stabilisation of root ablaut. Here belong:

a) $C a ́ C$-van- $\sim C a ́ C$-uș- neuters, continuing (through an early paradigm split) the group of PIE proterodynamic neuter heteroclites *CéC-ur-/*CC-uén-;

$\beta)$ The proterodynamic/acrostatic neuter $s_{u}$ var '(sun)light; sun', $\mathrm{W}$ analogically súr ${ }^{7}$ but Gsg., Lsg. $s_{\dot{u}}$ var $<*^{*} \operatorname{sú}_{2}-l-l$

\footnotetext{
${ }^{6}$ An exception to this is the numeral (an old dual) aștá 'eight' $<{ }^{*} H_{2} o k$ - $t o ́-$ $H_{1}$, which behaves exactly like sás 'six', being synchronically an entirely opaque formation and therefore in its oblique cases, which are in any case completely secondary creations, adapted to the pattern of root nouns. The curve may originally have been mesocolumnar, i.e., synchronised with the pattern of feminine $\bar{a}$-stems, and would have probably stayed as such if it were not for the peculiar end-accented genitive plural form (aștānám), which, as is plainly obvious, had been levelled in from the rest of the numerals in the 5-10 group. As such, aștá, having no analysable suffix, was in fact closer to sás than to an $\bar{a}$-stem and would have changed its allegiance accordingly.

${ }^{7}$ The hapax legomenon sūré in RVS IV.3.8b displays peripheral transition into the pattern typical of root nouns, since eventually at least the
} 
$*_{s u H_{2}}$ én- (< PIE *séH $H_{2}$-ul- *sóH H $_{2}$-ul-/*suuén- < *s-uén- < $*_{S} \mathrm{H}_{2}$-uén- < * $\mathrm{SH}_{2}$-uén- * *éH $\left.\mathrm{H}_{2}-u n-\right)$;

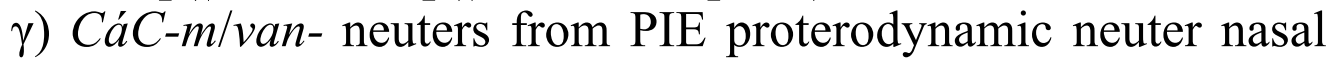
stems *CéC-mn-/*CC-mén-;

ס) Probably svá-sar-, W svá-sr- <*sué-sor- * sué-sr- 'sister' (if it is assumed that the first member of such a compound would not have exhibited an active ablaut pattern in PIE (*sué-: ${ }^{* *} s u$-) and hence had a fixed accent on *sué- while regularly ablauting the second member; otherwise to be treated under $\varepsilon$. below);

ع) v'rss-an- 'bull (of a man); virile, vigorous' < PIE * $\left(\mathrm{H}_{2}\right)$ uŕss-en(either by an old, purely oppositional accent ${ }^{8}$, for which $\mathrm{cf}$.

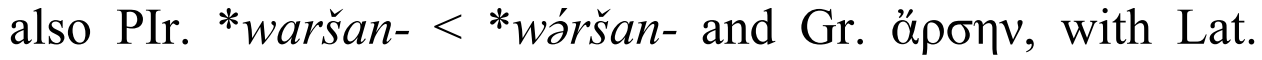
verrēs being ultimately ambiguous, or for original ${ }^{*} \mathrm{H}_{2}$ uérson- $/{ }^{*} H_{2}$ urs $\left.-n-{ }^{-9}\right)$;

$\zeta)$ All PIE holodynamic stems with levelled-out suffix-accentuation in originally trisyllabic strong cases and concomitant stabilisation of root ablaut: ${ }^{*} \mathrm{CéC}-\mathrm{oC}$ - vs. ${ }^{*} \mathrm{CeC}-\mathbf{o} \mathrm{C}-(\mathrm{C}) \mathrm{V}^{\circ}$ (by the $k^{u}$ etuores-rule) $\Rightarrow{ }^{*} \mathrm{CéC}-o \mathrm{C}$ - vs. ${ }^{*} \mathrm{CéC}-o \mathrm{C}-(\mathrm{C}) \mathrm{V}^{\circ}$, including the derived (originally mesodynamic) feminatives. Here belong:

$\left.\alpha^{\prime}\right)$ Comparatives in $C a ́ C-(\bar{l}) y a(\dot{m}) s-, \mathrm{W} / \mathrm{M} C a ́ C-(\bar{l}) y a s_{-}{ }^{10} \leftarrow$ PIE holodynamic *CéC-ios-/CéC-is-;

$\left.\beta^{\prime}\right)$ All $C a ́ C$-tar-, i.e., habitual, agent nouns (including the synchronically associated bhrá-tar- 'brother' and náp-

secondary weak stem could have been interpreted as belonging to that category, but note that in this particular case such a nonce accentual transgression was probably (additionally?) prompted by the following adjective brhaté. The neo-prevocalic stem itself is of course entirely analogical (paralelly also in Young Avestan) and easily imitates the ratio in the only other structurally comparable stem available, which was yúvan- : yún- $<* i u H a n-$, *iuHn-.

${ }^{8}$ A parallel case may also be úr-an- 'lamb' $\leq * u r H_{1}$-én-, whose secondary barytonisation must be at least Indo-Iranian (vs. Gr. $\dot{\alpha} \rho \eta v$ ), judging from

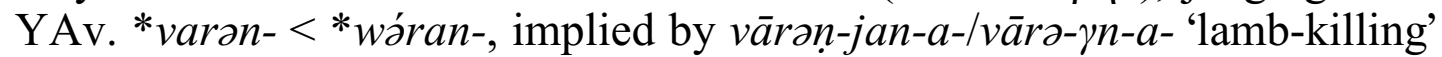
(see Hintze 1994: 189 for the attestation and its interpretation), a vārâra-

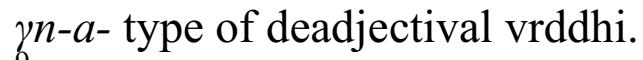

${ }^{9}$ Cf. Peters 1993: 397.

${ }^{10}$ The oblique stem of Vedic comparatives is adapted to the pattern of $-v /$ mant-stems, from which it also (just like the perfect participle) draws its secondary nasal in the strong stem: *-wänt- (the length analogical to the pf. ptcp.) vs. *-ina $N s_{-}=*_{-}$wat- $: \mathrm{x}=>*_{\text {-inas- }}$. 
tar- 'descendant, (grand)son'11, but excluding mā-tár'mother', which takes on the accentual profile of its antonym pi-tár- 'father'), going back to PIE secondarily barytonised originally holodynamic derivatives in *-ter-;

$\left.\gamma^{\prime}\right)$ The very few survivors of PIE holodynamic nasal stems in $*_{-}(\mathrm{m} / \mathrm{v})$ en- with preserved root accentuation (such as áś-mān- 'stone' < * ${ }_{2}$ ék-mon-, tákṣ-an- 'carpenter' < $* t e ́=t k$-on-, and rấj-an- 'ruler' $<{ }^{*} H_{3}$ ré̀̆ǵ-on- $)^{12}$;

$\left.\delta^{\prime}\right)$ The only inherited holodynamic $i$-stem to survive in Indo-Iranian, viz. sákh-āy-/sákh-i- 'companion' < *sók $k^{u}-$ $\mathrm{H}_{2}-\mathrm{O} \mathrm{i}-{ }^{*}{ }^{*} \mathrm{SOk}^{u}-\mathrm{H}_{2}-\mathrm{i}-$;

घ') The nasal stems yúvān-, W yún-, M yúva- 'a youth; young' < *iúu-Hān-/*iún-/*iú-Ha- $<*^{*} \mathrm{H}_{2} i \dot{u}-\mathrm{H}_{3} \mathrm{On}-{ }^{*} \mathrm{H}_{2} i u-$

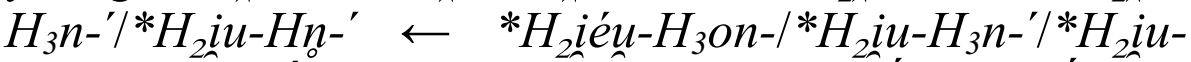

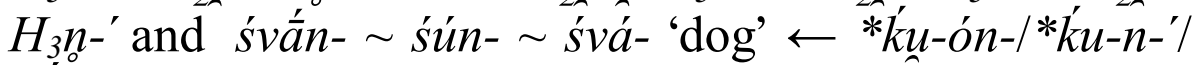
$* k u-n-$ ' by virtue of the strong stem śván- having been interpreted as equivalent to the root morpheme;

$\eta)$ All proterodynamic vocalic stems with retained rootaccentuation in the strong stem, thus, in effect, $C a ́ C-i$ - and $C a ́ C$ - $u$ - derivatives;

II. The mesocolumnar $A C$

Inherited members:

a) Oxytone thematic stems (including their feminatives in *-é- $\left.H_{2^{-}}\right)$;

b) Mesostatic vocalic stems involving the accent-attracting suffixal conglomerate ${ }^{*}-i-H_{2^{-}}$(originally probably so at least when dethematic);

c) Individualised relational derivatives in -in-, which, since bound to $O$-stems $\left(*_{-} O-\rightarrow^{*} i_{-}+*_{-}-n\right.$-) could display no ablaut in the suffix and hence were immune to any kind of accent movement;

\footnotetext{
${ }^{11}$ Though originally and in the strong cases (as well as in the relic middle stem nád- $<* n a b d-<* n^{e} p t$-) still a dental stem (PIE *nép-ot- if not indeed *né-pot-), náptar-is synchronically essentially suppletive, behaving as any root-accented -tar-stem in the weak (and the middle) cases (back formed from the neo-genitival form *náptarš > náptur, which arose by semantic association, as was also the case with sákhyur 'companion', pátyur 'husband' and jányur 'wife').

${ }^{12}$ Note that óman- in RVS V.43.13b is a neuter action noun 'aid, support' and not an agent noun (pace RiVeLex II s.v.), as also correctly recognised in Schneider 2010: 124-125.
} 
d) (-ís-),$-u s^{-13}{ }^{13}$, and -ás- animates, since these were simply matrix oxytone internal derivatives to their already non-ablauting inanimate pairs, replicating (and in the case of sigmatic es-stems probably indirectly continuing) the inherited derivational ratio *CéC-C- $\rightarrow$ *CC-éC-;

Newcomers:

a) All -iśs-neuters (with the exception of jyótiș-, for which see above) by analogy with the kravis-type, where accent progression was regular by Lubotsky's Law $^{14}$ (this also explains why only those stems whose suffixal vowel could synchronically be identified with $*_{i}<{ }^{*} H$ were affected by this apparently across-the-board oxytonisation process);

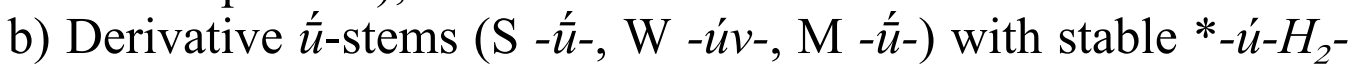
(under the pressure of their structural and functional counterparts,

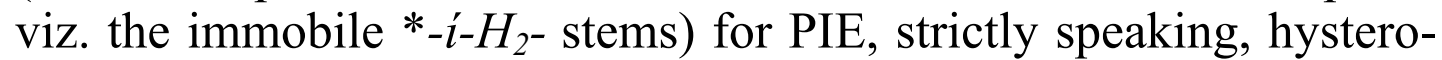
dynamic *-u-é $H_{2}-{ }^{*}-u-H_{2^{-}}$, but in terms of what synchronically would have appeared to be the suffix in fact already inherited as superficially mesocolumnar;

c) Polysyllabic derived mobiles with generalised suffixaccentuation if and only if originally uncapable of desinential accentuation in the weak cases - a group which naturally comprises all proterodynamic $-i$ - and $-u$ - stems with unretained rootaccentuation in the strong stem. The only exception to the otherwise steadily columnar curve is the genitive plural, which beyond any doubt reflects the relic accent position (cf. Nielsen 2009: 386 for the same view), as is proved by the steadily suffix-accented genitive plural in the immobile purușí- $\sim \tan \bar{u}$-type (which would even under different circumstances, i.e., had the case form in question not been subjected to a remodelling under the influence of the properly vocalic stems, simply have been **-ii-aHam). This view basically amounts to claiming that in structural terms the renewed Gpl. of

\footnotetext{
${ }^{13}$ Here with a few secondary exceptions such as tápuṣ- 'hot', cákșuṣ'seeing' and vápuș- 'wonderous' due to their synchronic root-ablaut restrictions (**tp-, *kss-, **up-) and subsequent accent relegation (as in, say, unreduplicated thematic aorist, where ${ }^{*} C a C-a ́-\quad<{ }^{*} C^{e} C$-á- basically regularly $\rightarrow C a ́ C-a-)$.

${ }^{14}$ For the formulation of which see Lubotsky 1992.
} 
vocalic stems $(-\bar{V} n a \cdot a m \sim-\bar{V} n \bar{a} m)$ still functioned as a fundamentally vocalic desinence ${ }^{15}$;

d) The only surviving holodynamic sigmatic stem $u s$-ás- 'dawn' $<{ }^{*} \mathrm{H}_{2} u s$-ós- $\leftarrow{ }^{*} \mathrm{H}_{2}$ eus-ós- $<{ }^{*} \mathrm{H}_{2}$ éus-os- by virtue of its having been drawn into the group of animate immobile (mesocolumnar) sigmatic stems in -ás- (but with a residue of a synchronically defective since morphologically opaque -, though essentially mobile Gsg. usás and Apl. us-ás), although typologically comparable to the above cases of holodynamic stems with levelled-out suffix-accentuation in originally trisyllabic strong cases;

e) The inherently immobile possessive (relational) adjectives in $-v /$ mant- whenever the derivational base was a disyllabic oxytone $-i-,-u^{\prime}-,-(a ́) r$ - or -án- stem (cf. the above mentioned acrocolumnar counterparts and $\mathrm{v}$. inf. for a full discussion);

f) The perfect participle active $C V-C C-v \bar{a}(N) s-, \mathrm{W} C V-C C-u ́ s-$, $\mathrm{M} C V$-CC-vát-, heavily remodelled from PIE holodynamic ${ }^{*} C e$ -

${ }^{15}$ This is in effect also the AC category to which the monosyllabic $i$-stem vélís and, via its G/Abl. sg. gós (see above), the root noun gă̋ $v$-belong, behaving, as they do, exactly like disyllabic $i$-/u-stems with suffix accentuation in the strong cases (i.e., synchronically, a mesocolumnar type with residual end-accentuation in the genitive plural). Note, however, that in the case of vé-/ví- no prevocalic weak stem is actually attested, but a form like *váye for the Dsg. is actually more than certain on the evidence of the Gsg. vés. As far as I am concerned, the Indo-Iranian paradigm is most elegantly explained as reflecting an old acrostatic stem *(s) $\mathrm{H}_{2} u o$ íis $/ *(s) \mathrm{H}_{2}$ uéeis (concerning the $s$-mobile consider pre-Anatolian * suóis by regular deletion of the laryngeal in a tautosyllabic ${ }_{s} H R$. sequence, but note Nikolaev 2009: 477, who would rather see here the result of de Saussure's Law, which, of course, depends on the relative ordering of the two phenomena), which, after yielding the attested Nsg. *wáiš and Gsg. *wáiš (the Dsg. being simply *wái-ai and the Gpl. *wái-aHam) was subjected to a regularisation on the model of the proterodynamic $i$-stems (the only other category to have had an *ái-šs sequence in the Gsg.) by the proportion ${ }^{*}$-ai-šs $:{ }^{*}-i-\check{s}=*^{*}$ wáiš $: x=>*^{*}$ wišs, whence the middle cases in *wi- alongside the Vedic end-accented genitive plural form (against the old, basically static Av. vaiiam), which in its mobility cannot but copy the pattern of mesocolumnar $i$-stems (see, however, Zair 2011 for a radically different view of things). This is also the reason why the genitive plurals of $g \stackrel{\underline{a}}{v}$ - and véli- differ, the former preserving the old root-accented form (gáv-ām, with a secondary gó-n-ām by treating the oblique $g o$ - as a basically vocalic stem), while the latter inevitably copies the end-accented Gpl. from the stem-type which it also follows morphologically. 
CeC-uós-/*Ce-CC-us-' $\leftarrow \quad{ }^{*} C e-C e ́ C-u o s-/{ }^{*} C e-C C-u s-'$ under the influence of (suffix-accented) adjectives in $-v /$ mant- (see below);

g) The muddied compound anad-vắh- (Nsg. *anad-wắns $\leftarrow$ *anad-wás $<*$ anad-wắs $<*$ anad-wắts $\leftarrow$ *anad-wát $/)$, W anaḍ-úh-

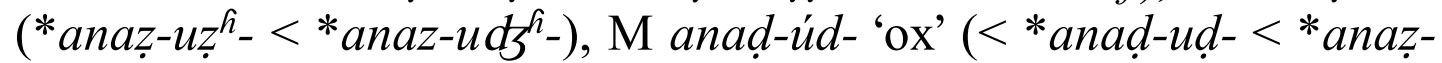
$u z-)$, whose second member was remodelled under the influence of the perfect participle active for PIE $*^{*} H_{3} e n=o s-u o g^{\prime} h_{-} /{ }^{\circ} u g^{\prime}{ }_{-}$'and therefore either copies the latter's accentual profile or, which is more likely, has simply acquired a secondary immobile character since it appears in composition (a fate that would arguably have also affected ${ }^{\circ}$ hán- if it were not for the non-nucleic structure of the root in prevocalic position: ${ }^{\circ} g h n-$, so that the accent had to be relegated to the next possible vowel, which, under this view of things, simply happened to be the ending);

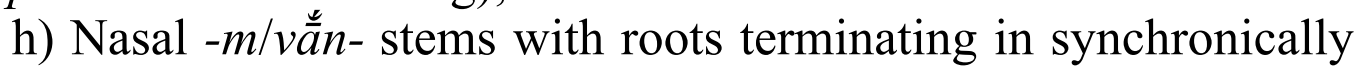
segmental consonants, for the very banal reason that these (with a few very archaic exceptions that rather display the application of the áśnas-rule, namely Isg. áśna , Gsg. áśnas $<*{ }^{*} H_{2}{ }^{\prime} k-n-V<* H_{2}{ }^{e} k-m n-V-$ and the practically adverbialised mahina $\left.*^{*} m^{e} \dot{g}=H_{2}-m n-e ́ H_{1}\right)$ systematically ousted the prevocalic zero-grade allomorph of the suffix and hence equalised it with the strong form a procedure that naturally induced accent relegation: $-C-m / v \stackrel{\circ}{a} n-$ $\rightarrow-C-m / v$ án $-V\left(<*_{-} C-m / u n n-V-\right)$;

i) Adjectival "derivatives" in $-\dot{a}(N) c$ - from adverbs (and secondarily but only marginally also nouns) ending in ${ }^{\circ} a$ - whenever the adverb/the derivational base itself was oxytone, ${ }^{16}$

j) The fragmentarily attested nasal stem kaniyan- 'a (young) girl' (see excursus for an explanation).

\footnotetext{
${ }^{16}$ Note that this also includes viśva- 'all, every' by virtue of its being systematically oxytone when compounded, so that viśva- : viśvá $\rightarrow$ *wífwá-Ha(N)ty- > viśváánc- viśvắc/k- 'facing every (single) direction'.
} 


\section{$\S$ 1.1.2. Mobile patterns}

\section{$\S$ 1.1.2.1. Marginally mobile patterns}

III. The amphidynamic $A C^{17}$

a) All simplex root nouns (be it mobile or immobile from the point of view of their PIE accent and ablaut pattern, in the latter case on analogy with the e/ $\emptyset$-ablauting mobile class), but excluding the originally immobile $g \stackrel{\check{a}}{v}$ - (which due to its G/Abl.sg. gós, synchronically equatable and indeed equalised with -ó-s of sünós \& c., was accentually clinched and thus petrified under the pressure of the immobile contour of polysyllabic $u$-stems; cf. the case of vé-/vi-, which, through G/Abl.sg. vés essentially does the exact same and takes on the structure-catered equivalent of the mesocolumnar pattern), including the secondarily immobilised nár- (for which see above), and the reinterpreted aorist participle active dánt- $\sim$ dat-' $<$ ${ }^{*} H_{1} d$-ént-/*$H_{1} d$-not-' by virtue of an early escape (via lexicalisation) from the remodelling that generally affected all mobile present and aorist active participles, as well as the synchronically ablaut-less náus, W nāv-', M nau-' 'boat', which after contraction (*náHu-, *náHu-) takes on synchronic opacity and starts to behave in all respects as a root noun and as such simply follows the pattern of the likes of $v \bar{a} c-\sim v \bar{a} c / k^{-18}$. This category naturally also involves all monosyllabic $\bar{l}$ - and $\bar{u}$-stems $\left(={ }^{*} \mathrm{Ce} i \mathrm{H}-/{ }^{*} \mathrm{CiH}\right.$ - and ${ }^{*} \mathrm{CeuH}-{ }^{*} \mathrm{CuH}-$ root nouns with generalised zero-grade roots), with strí- 'woman' being a secondary addition ${ }^{19}$ on purely structural principles (S str-îl-,

${ }^{17}$ Note that this is the only category in Vedic that regularly accents the consonantally anlauting desinences. In other words: does not differentiate between the weak and the middle cases. This is immediately understandable from the fact that no member of this accentual class actually possesses a synchronically analysable (cf. in this respect particularly the case of pum̌s-' $\sim$ pum-') suffix.

${ }^{18}$ As far as the Apl. forms are concerned (which in Indo-Iranian count as weak), it is well known that these show an increasing tendency to copy the strong (i.e., root) accentuation of the Npl., regardless of whether they display diverging ablaut grades (in which case the unification process may also affect the latter aspect). In the case of monosyllabic $\bar{l}$ - (including strí-) and $\bar{u}$-stems, the result of this process has been virtually regularised, since here the forms were synchronically identical and were equalised under the pressure of *-iias : *-ías, *-úwas : *-úwas in the mesocolumnar $\bar{l}-\bar{u}$-stems. ${ }^{19}$ Since, etymologically speaking, this is a (haplologised; see Dunkel 2016) derived noun, it should be seen as primarily hysterodynamic, just as any 
secondarily then also str-íy- on analogy with the $d h \bar{l}$-type, W striy $\bar{a}^{\circ}$ $<*^{*}$ str $-y \bar{a}^{\circ}$ by Sieverisation, M str-ī- $C^{\circ}$ );

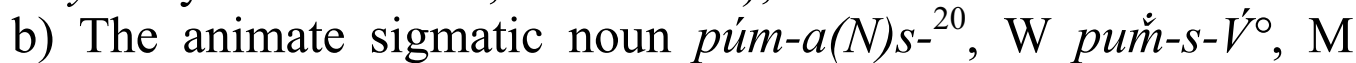
pum-bh $h^{\circ \prime}(<*$ pumz- $) \sim$ pum̆- $s^{\circ \prime}$ 'male' < *púm-os- $/{ }^{*}$ pum-s-' $\leftarrow$ PIE 'péum-os-/*pum-s-', since in the weak stem the suffix lost its vocalic nucleus that should have otherwise attracted the accent. Note that although these circumstances could also be viewed from an opposite angle, that is assigning pum-a(N)s- $\sim$ pum-s-' to the underlyingly holodynamic type with the „middle“ form then simply failing to attract the accent, we would in such an event undoubtedly expect the accent to have been immobilised to **pum-a $(N)_{s^{-}-~}$ **púm-s- $* *$ púm- as in any other originally mobile derived stem with root-accentuation in the strong cases and stabilised root ablaut, so that it is obvious that pum-a(N)s- behaves accentually as a monosyllabic root-noun and does so precisely due to the fact that it lacks a synchronically analysable suffix in the oblique.

IV. The proterodynamic $A C$

This small group consist of only three relics, all involving the descendants of originally acrostatic PIE neuters with secondarily developed marginal mobility: *dór-u-/*dér-u- $\rightarrow * d r$-éu- $>$ dấr-u-

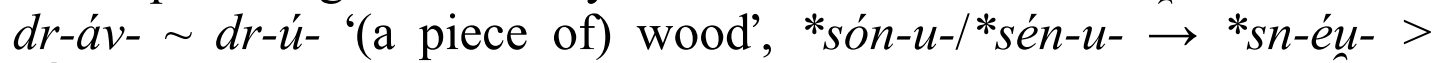
sấn-u- $\sim$ sn-áv- $\sim$ sn-ú- 'ridge' and *gón-u-/*gén-u- $\rightarrow$ *ǵn-éu- >

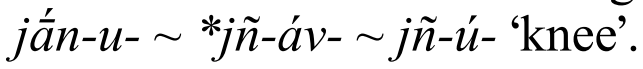

V. The hysterodynamic $A C^{21}$

Inherited members:

a) Originally hysterodynamic ( $-i$ - and) $-u$ - stems with retained suffix-accentuation in the strong stem (alongside their expected standard residual genitive plural forms in $-\bar{\imath} / \bar{u}-n-\bar{a} m$ ), including the PIE hysterodynamic $u$-stem dyáus, $\mathrm{W} d i-v-V^{\circ}, \mathrm{M} d y$-ú-C $C^{\circ}$ 'sky' < *di-éu-/*di-un-'/*di-u-';

mobile $\frac{i}{l}$-stem. Its actual amphidynamic pattern, then, cannot reflect the primitive state of affairs.

${ }^{20}$ The nasal is secondary (and ultimately borrowed from $-v /$ mant-stems), as in all masculine sigmatic stems.

${ }^{21}$ The locative singular of all nasal, $u$-, and $r$-stems regularly appears in the full grade ( + the increasingly obligatory $-i$ as the ending proper to this case) and is as such expectedly suffix-accented (reflecting the inherited shape of the PIE endingless locative). 
b) The active present/aorist participle of oxytone thematics $\left(-a^{-}-\right.$ $n t-, \mathrm{W}-a t-V^{\circ}, \mathrm{M}-a^{\prime} t-C^{\circ}$ );

c) Stems in plain and complex nasal suffixes $-(m / v) \stackrel{\llcorner}{a} n_{-}{ }^{22}$, continuing both holo- and hysterodynamic PIE nasal stems alike (in the case of the latter completely naturally and as far as the holodynamic PIE starting point is concerned, involving all those instances that generally avoided a generalisation of root-accentuation in the strong cases). This category also includes the verbal noun 'hán- ${ }^{\circ} g h n^{\prime}{ }^{\circ}{ }^{\circ} \dot{a}^{-}<{ }^{* \circ} g^{u h} e ́ n-,{ }^{\circ} g^{u h} n-,{ }^{*} \circ g^{u h} n_{0}$ as a second member of verbal governing compounds, which was, in terms of its superficial structure, interpretable as effectively a nasal suffix (cf. supra), as well as the plural oblique stem of secondarily $n$-stemmed heteroclite neuters (for which see below);

d) The only reconstructible PIE holodynamic nasal stem in

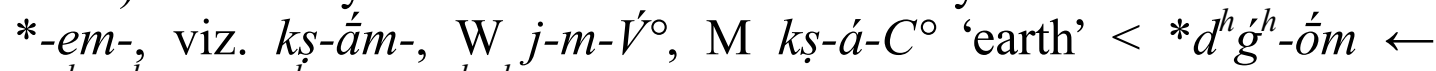
$* d^{h} \dot{e}^{\prime h}-\bar{o} m / *^{\prime h}-m-{ }^{\prime} / * d^{h} \dot{g}^{h}-m-^{\prime}$;

e) The mobile present/aorist active participles in -ánt-, $\mathrm{W}-a t-V^{\circ}$, $\mathrm{M}-a ́ t-C^{\circ}<*_{-}^{*} e ́ n t-/-n t-'$, including the functionally adjectivised $b r h-$ ánt- 'elevated' $<* b^{h} r g^{h}$-ént- and its early contamination victim mahấnt-, W mah-at-', M mah-át- 'great, big' < *m ǵg-éH $H_{2}$-ont-l *m $m^{e} \dot{g}-H_{2}-n t t^{\prime}$

f) The survivors of PIE hysterodynamic, i.e., non-habitual agent nouns in $\mathrm{S}$-tár-, W -tr- $V^{\circ}, \mathrm{M}$-tŕ- $C^{\circ}<\mathrm{PIE} * C C$-tér-/*-tr-'/*-tr-';

g) The suffix-accented counterpart of pánth-ā-/path-'/pathi'path, road' (for which see below), viz. *még'-oH${2^{-}}^{*}{ }^{*} m^{e} g$-ó $H_{2^{-}}>$ $\mathrm{S} m a h \underline{a}-,{ }^{*} m^{e} \dot{g}-H_{2}-V^{\circ}>\mathrm{W} m a h-V^{\circ},{ }^{*} m^{e} \dot{g}-H_{2}-C^{0^{\prime}}>* m a d z H^{\prime}-C^{\circ r}>$ ${ }^{*}$ mad $\zeta^{h} i-C^{\circ \prime} \rightarrow$ mah-i- $C^{\circ}$ 'great, big ${ }^{23}$ with a secondarily developed nucleus in the preconsonantal weak stem, which, as far as its role in a mobile trimorphemic sequence was concerned, was synchronically identified with and began to function as the suffixal morpheme.

\footnotetext{
${ }^{22}$ As far as masculine man-stems are concerned, their hysterodynamic AC is mostly due to a synchronically productive polarisation between neuter action nouns (*CéC-mn) and their animate (masculine) internal holodynamic possessive derivatives ( ${ }^{*} C e ́ C$-mon- $\rightarrow{ }^{*}$ CeC-món-).

${ }^{23}$ With the notable exception of the archaic, root-accented NAsg. ntr. máhi $<* m e ́ g ́-H_{2}-\emptyset$.
} 
Newcomers:

a) All oxytone ablauting $-\frac{\dot{l}}{-} \sim-y \frac{\dot{a}-}{-}$ stems, continuing PIE proterodynamic and mesodynamic ${ }^{*}-\mathrm{iH}_{2}-\mathrm{-}_{-} e^{2} \mathrm{H}_{2}$ - derivatives ${ }^{24}$;

b) The originally probably acrostatic $i$-stem $* r e ̂ ́ H_{1}-i-/ * r e ́ H_{1}-i$ - (as in *rếk-i-/*rék-i- 'the said thing') or, alternatively, *ró $H_{1-i-} /{ }^{*} r e ́ H_{1}-i-$ $>$ Ved. rayí-, W $r \bar{a}-y-V^{\circ}, \mathrm{M}$ ray-i- $C^{\circ}$ 'goods' ${ }^{25}$ by reason of a secondary, laryngeal-induced accent shift by Lubotsky's law;

c) Mobilised deadverbial (and, marginally, deadjectival) adjectives in $-\dot{a}(N) c_{-}$, comprising all cases that start from a disyllabic $-i-,-u$ - derivational base, regardless of the accent position in the simplex ${ }^{26}$.

\section{$\S$ 1.1.2. 2. Non-marginally/Fully mobile patterns}

VI. The holodynamic $A C^{27}$

a) The non-plural paradigm of secondarily mobilised acrostatic neuter heteroclites in $\left.*_{-}^{r}\right]_{n}$ - with preserved suffix-accented ending-

24 Although, diachronically speaking, such stems are intrinsically columnar, given that the ablaut is limited to the suffixal part only, the synchronic system most likely recognised and treated them as inherently mobile (quasi $*_{-\bar{l}^{-}}: *_{-} y_{-}$), which finds some support in what to all appearances must be the old accentuation of the genitive plural $(-\bar{l}-n-\bar{a} m)$ found in a few residual forms (see Wackernagel/Debrunner 1930: $\S 89 \mathrm{~d}$, cf. Wackernagel/Debrunner 1954: $\S 6 c \delta$ ). These can hardly be imitations based on the Gpl. of oxytone $i$-stems $(-\bar{i}-n-\bar{a} m)$, since otherwise the same oscillation would be expected in the other mesocolumnar $\dot{t}$-class (and its $\dot{u}$-stem counterpart). Such genitives, however, must have early on relocated the accent to the suffixal part on analogy with the accentual profile of the preconsonantal stem (for this phenomenon as a precondition for the rise of the contact form kaninam see the excursus).

${ }^{25}$ The only exception is the root-accented Npl. rấyas, which in all reality represents a back formation, based on the Apl. rāyás, following the model of root nouns.

${ }^{26}$ The sole exceptions to this rule being vís v-a(N)c- 'facing different directions' (surely under the influence of the regularly barytone compositional form viśs $u^{\circ}$ and in opposition to its near-homophone and nearsynonym $v i s v^{\circ} a^{\circ}$ and $s v-a ́(N) c$ - 'turning easily' to the secondarily adjectivised/adverbialised, synchronically properly prefixal $s u ́{ }^{*} H_{I} s-u$ - 'a good thing', again expectedly (and as opposed to, say, $n i \rightarrow n_{i} y a(N) c^{-}$) suffixaccented, given the synchronic fact that in compounds which inherently accent the first member $s u$ - regularly throws the ictus to the following member (and has effectively behaved so in *su-Há(N)tf-as well).

${ }^{27}$ Since this is a relic category, all its members are inherited. 


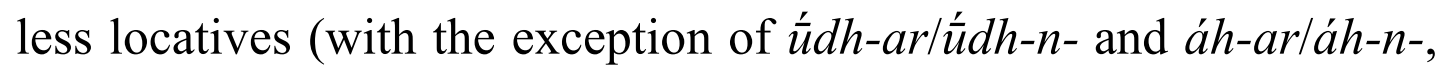
for which see above):

- ásr-k, W as-n- $V^{\circ}$, Lsg. as-án(-i) 'blood' < *ás-r-K-/*as-n-'/*as-án

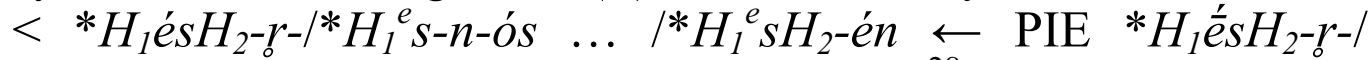
${ }^{*} H_{1} e ́ s H_{2}-n-\left(\rightarrow * H_{1}{ }^{e} H_{2}-e ́ n-\longrightarrow{ }^{*} H_{1}{ }^{e} S H_{2}-n-{ }^{-}\right)^{28} / * H_{1}{ }^{e} S H_{2}-e ́ n$

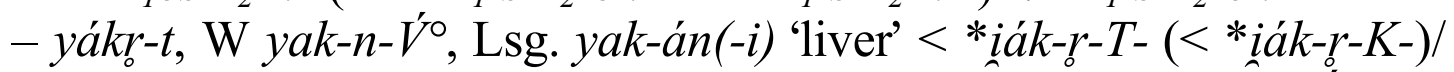
*iak-n-'/*iak-án < *iék $k^{u}-r-/ *_{i}^{e} k^{u}-n{ }^{\prime} / *_{i}^{e} k^{u}-e ́ n \leftarrow$ PIE *Hié $k^{u}-r-1$ ${ }^{*} H i e ́ k^{u}-n-\left(\rightarrow{ }^{*} H i^{e} k^{u}-e ́ n-\longrightarrow{ }^{*} H i{ }^{e} k^{u}-n-{ }^{*}\right) /{ }^{*} H i{ }^{e} k^{u}-e ́ n$

- śákr-t, W śak-n-V́, Lsg. śak-án(-i) 'excrement' < *fák-r-T$\left(<* \int a ́ k-r-K-\right) / * \int a k-n-{ }^{\prime} / * \int a k-a ́ n<* k e ́ k-r-/ * k^{e} k-n-{ }^{\prime} / * k^{e} k$-én $\leftarrow$ PIE *kók-r-/*kék-n- $\left(\rightarrow * k^{\prime} k\right.$-én- $\left.\rightarrow * k^{\prime e} k-n-{ }^{\prime}\right) / k^{\prime} k-e^{2} n^{29}$

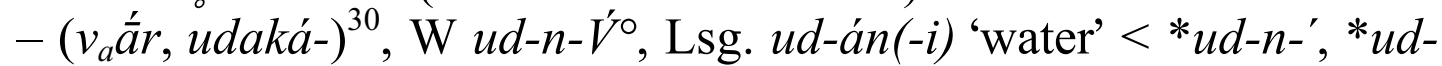
én $\leftarrow$ PIE *uód-r-/*uéd-n- $(\rightarrow *$ *ued-én- * *ud-én- $\rightarrow * u d-n-)$;

b) The non-plural paradigm of the group of four relic PIE ablauting (proterodynamic?) sigmatic stems with the oblique stem secondarily characterised by an *-en-suffix, back-derived from the *en-locative:

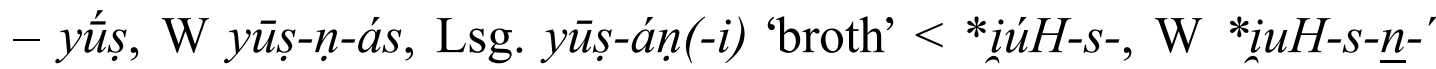
$(\leftarrow$ Lsg. *iuH $=s$-én $) \leftarrow *_{i} e_{e} u H-s-{ }^{*} i u H-s-'$

- dós, W doṣ-n-ás, Lsg. doṣ-án(-i) '(upper) arm' < *déu-s-/*deu-s-n$(\leftarrow$ Lsg. *de $u s-e ́ n) \leftarrow *$ déu-s-/*du-s-'

- *áas ${ }^{31} \rightarrow \bar{a} s_{i} y a m, \mathrm{~W} \bar{a} s-n$-ás, Lsg. ās-án(-i) 'mouth' <* ${ }^{*} H_{1} e^{\prime} H_{3}-s, \mathrm{~W}$ ${ }^{*} H_{1}{ }^{e} H_{3}-S-\underline{n-'}\left(\leftarrow \mathrm{Lsg} .{ }^{*} H_{1}{ }^{e} H_{3}-S-e ́ n\right) \leftarrow{ }^{*} H_{1} e ́ H_{3}-S-/{ }^{*} H_{1} H_{3}-S^{\prime}{ }^{\prime}$

${ }^{28}$ Such acrostatic weak stems were not stable in Proto-Indo-European and began early on to acquire secondary mobility (cf. Schindler 1975), first becoming descriptively proterodynamic on analogy with the endingless locative and thence, via this same case form, which structurally matched its counterpart within the corresponding holodynamic collective, endaccented.

${ }^{29}$ Probably as a transposed form only (but cf. EWAia. II s.v.), śák-r-/nalmost certainly being originally identical to Hitt. $\breve{s} / z a k k a r$ 'excrement' \&c. The diverging constitution of the root itself as reflected in Indo-Iranian seems to be due to either onomatopoeic or tabooistic distortion.

${ }^{30}$ The NAsg. is suppletive in Vedic (as in the case of $\bar{a} s_{i} y a-$ to $\bar{a} s-(a) n-$ 'mouth' and hŕdaya-, beside archaic hấrdi, to hrd- 'heart') < *uéH-r, $*$ ued $=n-k o ́$ - (but see Lubotsky for a different proposal).

${ }^{31}$ Forms like $\bar{a} s-\bar{a}$ (Isg.) and $\bar{a} s$-ás (Abl.sg.) are, given the Iranian data, most straightforwardly to be seen as archaisms $\left(<{ }^{*} H_{1}^{e} H_{3}-s^{-}\right)$, although in theory they could also reflect what synchronically must have appeared as a root noun (the category which it also follows accentually) after an early (read: internally Indo-Aryan) paradigm split of $\bar{a}_{s-}, \bar{a} s_{-}(a) n-\rightarrow 1 . \bar{a} s^{-}, \rightarrow 2$. $\bar{a} s_{i} y a-, \bar{a} s-(a) n-$. 


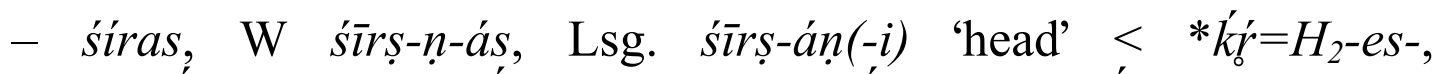

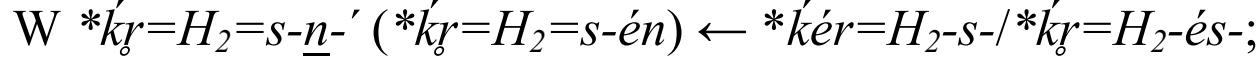

c) The non-plural paradigm of four nouns in a group of secondary $-i / n$-heteroclites (the $n$-stem obliques again back-derived from the *en-locatives, reinterpreted as endingless locatives to nasal stems):

- ákṣ-i-, W akṣ-n-ás, Lsg. akṣ-án(i) 'eye' (by back formation from the NAdu. ${ }^{*} a k \int_{l}^{\imath}<* H_{3}{ }^{e} k^{u}=S-i H_{1}^{32}$, reinterpreted as the NAdu. of a short $i$-stem)

- ásth-i-, W asth-n-ás, Lsg. asth-án(i) 'bone' < ${ }^{*} H_{2} e ́ s t-H_{2^{-}}$(old collective)

- sákth-i-, W sakth-n-ás, Lsg. sakth-án(i) 'thigh(-bone)' < sek $^{u} t-H_{2^{-}}$ (perhaps an old collective)

- dádh-i-, W dadh-n-ás, Lsg. dadh-án(i) 'sour milk' < *dá-dh $d^{h}-<$ ${ }^{*} d^{h} e^{\prime}-d^{h} H_{l^{-}}$'the thing that is repeatedly suckled out' $<*$ 'repeated suckling;

d) Any inherited holodynamic stems with root-acentuation in the strong stem and retained root ablaut, of which there are only two survivors:

a) pánthā- 'path, road', W path- $V^{\circ}, \mathrm{M}$ pathi- $\mathrm{C}^{\circ}<{ }^{*}$ pént-o $\mathrm{H}_{2}$ ' ${ }^{*}$ nnt $-H_{2^{-}}{ }^{\prime}$, with the suffix in the middle stem attracting the accent because it developed a secondary nucleus $\left({ }^{*} p n t-H_{2}-C^{\circ}\right.$ $>{ }^{*} p a t^{h} H^{\prime}-C^{\circ \prime}>{ }^{*} p a t^{h} i-C^{\circ \prime} \rightarrow$ path- $i-C^{\circ}$ ) by exactly the same principles that govern second-syllable accentuation in mah- $i$ $C^{\circ}$ (see above);

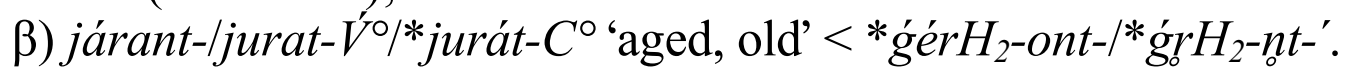

\section{$\S 2$. The rise of immobility}

As can be observed from the disproportionately large membership within the acrocolumnar type (AC I), of which only the minority is in fact inherited as such (three old acrostatic stems and all PIE barytone immobiles), the greater majority of accentually inherently mobile stems inherited from Proto-Indo-European were obviously transformed in the prehistory of Vedic into synchronically static types of paradigmatic accent. This situation obtained by the following rule:

Any polysyllabic derived mobile stem with preserved (either original or levelled-in) root-accentuation in the strong forms

${ }^{32}$ The $*_{-s-}$ is of course secondary on analogy with $* u f_{\imath}{ }^{\prime}$ 'ears' $<* H_{2} u s=s-i H_{l}$. 
and concomitant stabilisation of root ablaut ${ }^{33}$ is automatically immobilised.

This accounts successfully for all the cases enumerated under the acrocolumnar type $a$ through $f$ and is expectedly inapplicable to any inner-paradigmatic situation in which the accent of the strong form was either not originally on the root or was relegated to the suffix in what was either a primarily proterodynamic pattern or a choice between the two possible accentuations (as in the case of holodynamic trisyllables) $)^{34}$.

\section{§3. Mobility patterns in trimorphemic stems}

Seen from the vantage point of the circumstances that must have obtained in the proto-language (as still reflected in the case of synchronic amphidynamics), the only really problematic feature of both hysterodynamic and holodynamic accentual contours is their looping curve, and that for the reason that such a pattern is simply atypical in a system that generally inherited the correlation between obliqueness and accent progression (basically amounting to the PIE synchronic rule that, intraparadigmatically, no weak form may be accented on a morpheme that lies to the left of the morpheme that receives the accent in the direct/strong cases - a principle, by the way, that is also observed in the case of the endingless locative). The standardised rule to accent the suffix (or at least what under structural principles functioned as a suffix) before "consonantal" terminations $\left(-b^{h \circ}\right.$ and $\left.-s u\right)$ in the case of derived nouns that otherwise accented the vocalic endings is typical of mobile $r$-stems,

${ }^{33}$ Thus automatically inapplicable to cases such as járant- and pánthā-.

${ }^{34}$ Note, however, that the rule does not apply to numerals, which show what Nielsen (2009: 391 and 395) rightly calls the "mixed" accent pattern (though note that, contrary to her view of things, none of the nominal stems actually belongs there), as is the case with cáta-sr- 'four' (fem.) vs. cata-sgr$C^{\circ}$, náva 'nine' vs. navá- $C^{\circ}$ etc. This behaviour is purely analogical, however: páñca 'five', náva and dáśa 'ten' simply follow saptá 'seven' and aștá 'eight' and thus, ultimatively, aștấ, on which both the former and the latter are based (saptá as a rhyme-induced contamination and aștá as a crossbreed between the old form and the shape of the rest of this closelyknit group of numerals). The preconsonantal oblique $c a t a-s \dot{r}-C^{\circ}$, on the other hand, is an accentual imitation of $t i-s \dot{y}^{\prime}-C^{\circ}$, the difference between the accentuation in the NApl. itself being inherited from Proto-Indo-European (*tri-sór-es with an old accent shift by the * $k^{u}$ etuóres rule $\rightarrow{ }^{*}$ tri-sr-és as against the quadrisyllabic * $k^{u}$ éte-sor-es with inherent immunity to any such shift). 
nasal stems (including all cases of secondary $n$-stems, alongside the reinterpreted $\left.{ }^{\circ} h a ́ n-\right)$, non-columnar $u$-stems, $n t$-participles, the laryngeal stems mahắ- and pánthā-, (on prediction) járant-, and suffixaccented adjectives in $-\dot{a}(N) c_{-}$. Given the totality of members of this group, it appears that the rule would have applied to any mobile derived (i.e., possessing a suffix(oid)) stem that accented the ending in the weak stem; in other words those stems that retained their amphi- or hysterodynamicity in the domain of Rx-...-T[ $\left.\mathrm{V}^{\circ}\right]$ and $\mathrm{Sx}-$ $\mathrm{T}\left[\mathrm{V}^{\circ}\right]$ respectively. What seems peculiar at first sight then is the flat curve of a) suffix-accented $-v /$ mánt- stems, which do not accent the vocalic ending (there is no **-vat-ás etc.), and, to an extent even more surprisingly, b) perfect participle active, which was surely inherited as a holodynamic stem and should by any standard exhibit a hysterodynamic AC (with a Gsg. such as **-us-ás etc.).

The rise of the specifically Vedic hysterodynamic/holodynamic accentual contours is certainly to be sought, as was recently recognised by Keydana ( $f$ thc.), in the domain of those derived stems that regularly lost their nucleic substance in the suffixal part before terminations beginning with a vowel, which is, effectively, $-r-,-n-$ and vocalic (theoretically, but factually only $u$-) stems. Since under these circumstances the last two morphemes were monosyllabic entities $*_{-} C r-V^{\circ}, *_{-}(C) n-V^{\circ}, *_{-}-V^{\circ}$ and could be effectively perceived as "endings", so that in synchronic terms such forms appeared to be essentially and to all purposes bimorphemic, the rule [IN WEAK CASES, ACCENT THE FIRST VOWEL OF THE ENDING] was extended to preconsonantal position, so that ${ }^{*}-C r-C^{\circ \prime},\left({ }^{*}-(C) n_{0}-C^{\circ \prime}\right.$ $>) *_{-}(C) a-C^{\circ \prime}$ and $*_{-} u-C^{\circ \prime}$ were automatically adjusted to ${ }^{*}-C_{0}^{\prime}-C^{\circ}$, $*_{-}(C) a^{-} C^{\circ}, *_{-} u^{\prime}-C^{\circ}$, thus creating a sort of defective columnarity, in which, prevocalically, the suffix simply failed to attract the accent ${ }^{35}$, much to the same effect as in the case of ${ }^{\circ} h a n-{ }^{\circ} g n-V^{\circ} /{ }^{\circ} h a ́-$. Note that this will also account for the otherwise rather peculiar behaviour of accented root nouns in polysyllabic structures (most commonly in compounds). If these were synchronically perceived as basically suffixal, their columnarity is immediately explicable as analogically based on the model obtained in derived mobiles $\left({ }^{\circ} \mathrm{C} a \stackrel{a}{a}-v s .{ }^{\circ} \mathrm{CaC}-\right.$ $\rightarrow{ }^{\circ} C \stackrel{\check{a}}{C}$ - vs. ${ }^{\circ} \mathrm{CáC}$ - just like and, indirectly, exactly because under different structural circumstances ${ }^{\circ} \mathrm{Cá} / \mathrm{N}-v s .{ }^{\circ} \mathrm{Cr} / \mathrm{N}-{ }^{\prime} v s .{ }^{\circ} \mathrm{Cr} / \mathrm{a}^{\prime} \rightarrow$ ${ }^{\circ} \mathrm{Cá} r / \mathrm{N}-$ vs. ${ }^{\circ} \mathrm{Cr} / \mathrm{N}-{ }^{\prime}$ vs. ${ }^{\circ}{ }^{\circ} r_{r}^{\prime} / a^{-}$-). This innovation then automatically

${ }^{35}$ Cf. Keydana, op. cit., for a slightly different scenario and Nielsen 2009: 380-381, who essentially seems to have a similar reasoning in mind; Wackernagel/Debrunner 1954: §6a, however, is on the wrong track. 
spread to all derived stems that synchronically accented the vocalic ending in the weak stem, thus encompassing the $n t$-participles, the laryngeal stems mahóa- and pánth $\bar{a}-$, járant-, and deadverbial adjectives in $-\dot{a}(N) c$ - (which conveniently possessed a nucleic $*_{-} H_{a k}-<*_{-} H_{3}{ }^{e} k^{u}$ - by vocalic restitution in the heavy cluster that arose in preconsonantal position).

The puzzling case of the perfect participle, then, which, contrary to theoretically predictable circumstances, exhibits a fully mesocolumnar AC, is effortlessly solved. Taken with the equally problematic pattern of the $-v /$ mánt-adjectives, the former category is in fact a forma facilior (as already hinted at above): since active present participles had borrowed the pattern of -vánt-stems in their middle case-forms [stage 1] (see Repanšek 2019: 930-933 for the exact mechanism under which the two paradigms were synchronised), they expectedly also harmonised their originally hysterodynamic contour (the latter having been already achieved by the just discussed rule of accent retraction in the middle cases [stage 2]) with the immobile pattern $\left(-v /\right.$ mánt- : $-v /$ mát $-V^{\circ}:-v /$ mát- $\left.C^{\circ}\right)$ of their second-hand model [stage 3]:

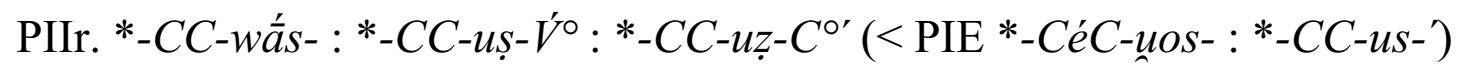

$$
\begin{aligned}
& \rightarrow \text { stage } 1 *_{-} C C-w a \bar{a} N_{s-}: *-C C-u s-V^{\circ}: *_{-} C C-\underline{w a t}-C^{\circ} \\
& \rightarrow{ }^{\text {stage } 2} *_{-} C C-w \bar{a} \bar{N}_{s-}: *_{-} C C-u \underline{s}-V^{\circ}: *_{-} C C-\underline{\text { wát }}-C^{\circ}
\end{aligned}
$$

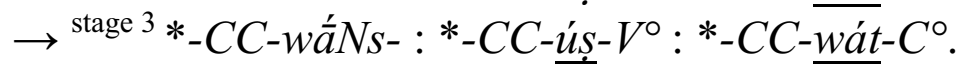

Our formae difficiliores, then, are really the "oxytone" $-v /$ mántstems, since at first sight it is rather unclear why there should exist no difference between the attested behaviour of the latter group of adjectives and the $n t$-participle. In other words, why $-v /$ mant- stems fail to display a hysterodynamic accentual curve. This finds an easy enough answer, however. The aberrancy, as it turns out, has nothing to do in fact with the innovation seen in derived mobiles in resonantfinal stems and its spread to the $n t$-participle. The crucial difference between the two categories is, namely, that the former - when mobile at all (i.e., derived from mobile presents and aorists) - are inherently suffix-accented, while $-v /$ mant-stems are fundamentally root-accented formations ${ }^{36}$, suffixal accentuation in that category being bound to very specific phonological circumstances, so that it only ever occurs if the derivational base itself was a disyllabic oxytone -í-, -ú-, -(á)r-, or -án- stem (e.g., paśú-: paśu-mánt- 'rich in

\footnotetext{
${ }^{36}$ This has very tentatively been suggested already by Nielsen 2009: 388, ft. 15.
} 
cattle; connected to cattle', agni-: agni-vánt- 'having fire in its vicinity', *raHí- $\rightarrow$ re-vánt- rayi-vánt- 'rich (in goods)', pūsáṇ-: pūṣaṇ-vánt- 'accompanied by Pūṣaṇ', mātár-: mātr-mánt- 'having a mother', see Wackernagel/Debrunner 1954: §709). That is to say: the accent rests under normal circumstances on the derivational base, but is automatically relegated to the following syllable if the accented part of the derivational base was an accented resonant or an approximant - a category of segmental phonemes that would regularly lose their nucleic accent-bearing core whenever pre-vocalic

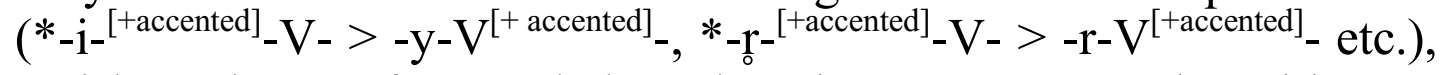
and by rule-transference behaved so in preconsonantal position as well whenever they were part of derivational bases or compounds. This rule is plainly observable in several other contexts, most prominently in Bahuvrīhis, which tend to accent the B-member of a compound whenever the first member is a disyllabic $-i$ - or $-u$-stem adjective (but there are many exceptions to this, the rule only being fully systematic in the case of $p u r u^{\circ}$ and $b a h u^{\circ}$ ), in comparatives and superlatives in the case of adjectival $u$-stems as derivational bases, and in Tatpurusas with a second member in -ta-, which under normal circumstances regularly accent the A-member but fail to do so whenever the latter is an $-i-,-u-,-(a) r-$, or $-a n$-stem (which basically amounts to saying that they do accent the A-member yet the accent is immediately thrown back to B) ${ }^{37}$. From this it follows that the accentual contour of $-v /$ mánt $\sim-v /$ mát- $V^{\circ} \sim-v /$ mát $-C^{\circ}$ is nothing but the result of accent-transference by one syllable, which then happens to be the suffix, resulting in the accentual paradigm's mesocolumnarity.

The only category that still requires its share of attention, then, is the group of originally deadverbial adjectives in $-a(N) c_{-}$, purely for the reason that the category is, just like the $-v /$ mant- possessives, accentually non-uniform (pace Matzinger apud Lühr 2008: 243, deficiently quoting Wackernagel/Debrunner 1954: §60). As it emerges from the classification in $\S 1$., these are mostly immobile, be it acro- or mesocolumnar, which will logically depend on the structure and the accent-placement in the derivational base (acrocolumnars: úd $\sim$ úd-a(N)c- 'facing upwards', ápa $\sim$ áp $\bar{a}(N) c$ 'facing backwards', párā $\sim$ párā $(N) c$ - 'facing away', prá $\sim$ prá $(N) c$ 'facing forward', ni $\sim n_{i} y a(N) c$ - 'facing downwards', vísu-

${ }^{37}$ Pace Nielsen 2009: 388, these shared morphophonemic peculiarities do not in any way point to the fact that $-a(n) c$ - formations were necessarily possessive compounds. 
vísva $(N) c$ - 'facing in all directions'; mesocolumnars: *arvà́ $\operatorname{arv} \bar{a}(N) c$ - 'turned hither', adhará̃ $\sim \operatorname{adhará}(N) c$ - 'facing downwards',

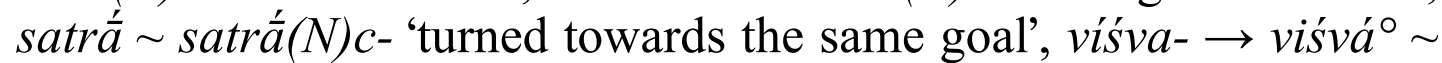
viśváa $(N) c$ - 'facing every direction', devá- $\sim \operatorname{deváa}(N) c$ - 'turned towards the gods', asmatrá $\sim \operatorname{asmatrấ}(N) c$ - 'turned towards us', cf. Scarlata 1999: 17-33 for further attestations), while disyllabic $-i-$ and $-u$ - stems, regardless of their accent, behave exactly like ${ }^{\circ}$ háncompounds. Given that it was obviously the structural conditions that were relevant for the selection of one or the other pattern and that these again superficially match the formal prerequisites for a shift in the accentual contour that turned out to be relevant in the case of $-v /$ mant-stems ${ }^{38}$, it is to be concluded as given that $-a(N) c$ stems were either a) inherently immobile derivatives and that the hysterodynamic $\mathrm{AC}$ in the few cases that fulfil the requirements for suffix/ending accentuation is secondary, or b) primarily mobile formations and that cases such as práti $\sim$ praty-á $(N) c$ - 'turned towards', ánu $\sim a n v-a ́(N) c$ - 'coming up from behind, following', purú- $\sim \operatorname{purv-á}(N) c$ - 'seeming to be plentiful', rjú- $\sim$ rjv-á(N)c'moving straightforward', śviti $\sim s^{\circ} v i t y-a ́(N) c$ - 'seeming to be bright', dádhi $\sim$ dadhy-á $(N) c$ - 'turned (in attention) towards sour milk', *tiri' $\sim$ tiry-á $(N) c$ - 'transverse', sam-y-á(N)c- 'facing the same direction', $s \dot{u} \sim s v-a ́(N) c$ - 'turning easily' (see above for the explanation of this seeming exception) etc. are in fact the only survivors of the original situation.

Given that all the above instances (including the very marginally attested passively interpretable cases) are, seen etymologically, verbal governing compounds in $*_{-} H_{3} e k^{u}$ - 'looking' $\rightarrow$ 'facing/being turned towards' (the $-n$ - of the strong cases being clearly secondary) and that these without exception stress their second members in Vedic, it seems that the right view of things must be the one that matches the scenario implied under b) and that in the case of $-a(N) c$ "derivatives" the accent was regularly relegated to the derivational base unless the base itself was an $-i-,-u-(-(a) r-,-a n-)$ disyllable or an element that would in a compound have automatically thrown the

\footnotetext{
${ }^{38}$ The reason that it is only in the latter category that also $-(a) r$ - and -anwill normally feature as stem-suffixes of a derivational base with these same inclinations lies in the banal fact that we simply do not have any structurally corresponding adverbs and neither does any of the adjectives/nouns attested in this category belong to $r$ - or the nasal stems, so that the seemingly narrower conditioning is coincidental and therefore entirely superficial.
} 
accent back to the second member (as in the case of $s u^{\circ}$ ), a situation reminiscent of, say, Tatpuruṣas of the $[\ldots-i-/-u-]-[\ldots-t a-]^{+a c c}$ type. This can actually be proved on the basis of Avestan, which clearly attests to originally second-member accentuation in such adjectives, even in the case of monosyllabic - $i$-stems, where Vedic decidedly exhibits the immobilised type. There are very few deadverbial adjectives in $-a(n) c$ - attested in Avestan and as far as the pre-vocalic strong stem is concerned, it is exactly niiänc-, the equivalent of Ved. $n_{i} y a \tilde{n} c_{-}$, that appears to be the sole survivor of the original category. The equation, however, is not perfect, since niiänc- (cf. Npl. niiänc$\left.\bar{o}<*_{n i i} a n t-a h\right)$ displays the reflex of what seems to be the "lengthened" grade, which looks as if the derivative simply generalised the suffixal form from the contexts which underwent regular contraction $\left({ }^{* \circ} a-H a n k / \check{c}_{-}>*^{\circ} \bar{a} n k / \check{c}-\right)$. There is a better solution to this apparent aberrancy, however. Given that Young Avestan systematically syncopates all unaccented inherited $*_{i i}$ sequences with concomitant compensatory lengthening, realised on a following, accented short $a\left({ }^{*} a>\bar{a} / \mathrm{i}>\emptyset \ldots\right.$, as in, e.g., viiädar ${ }^{2}$ sam $<*$ wii-á-darsam 'I saw clearly' etc.), what we have in niiånc- is in fact a perfectly regular development *ni-Hántf- $>$ *niiántf- >

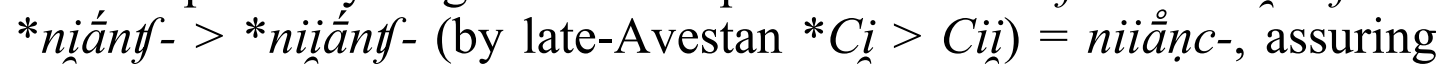
for the Proto-Indo-Iranian stage a *ni-Hánt - rather than pointing to **ni-Hant - -, which must then, one way or another, be an innovation of Vedic alone. This would also explain why it is both oxytone and barytone (!) - $i$ - and $-u$ - stems that shift the accent: if the accent was not in fact shifted but only remained on the suffixal part in such cases by associating the inherited structure with the likes of agnivánt- or puru-rúpa- \& c., CáCi/u- and $C a C i ́ / u ́$ - first members would be equally treated, since here the nucleic ending was analogically eliminated by regularising the Sievers-type sequences to reflect the desyllabified vocalic ending of the derivational base, followed by what was synchronically an $-a(n) c / k$ - suffix: *prati-Há(n)t/k- > *pratiiá $(n) t^{\prime} / k-\neq * *$ prati-iá $(n) t^{\prime} / k$-, therefore $\rightarrow$ prati-á(n)t $t^{\prime} / k-$. If so, the mobile pattern displayed by Ved. $-a ́ n ̃ c-\sim{ }^{-} c-\hat{V}^{\circ} \sim-a ́ k-C^{\circ} \leftarrow$ $*_{-} H a ́ t f-\sim *_{-} H t f-V^{\circ} \sim *_{-} H a ́ k-C^{\circ} \leftarrow *_{-} H_{3} e ́ k^{u}-\sim *_{-} H_{3} k^{u}-V^{\circ} \sim *_{-} H_{3}{ }^{e} k^{u}-C^{\circ}$ is then exactly that of $*_{-} d g^{h} a ́ n-\sim *_{-} g^{h} n-V^{\circ} \sim *_{-} g^{h} \dot{a}-C^{\circ}$ 'killing, destroying' $\leftarrow *_{-} g^{u h} e^{\prime} n-\sim *_{-} g^{u h} n-V^{\circ} \sim *_{-} g^{u h} n-C^{\circ}$, both with consistent adaptation to the new, defectively columnar $\mathrm{AC}^{39}$. The reason for the secondary relegation of the accent to the derivational base in the case of immobile $-a(N) c$ - formations was the inevitable conse-

${ }^{39}$ But see Keydana, $f$ thc., for a drastically different view. 
quence of morphological and semantic/functional obscuration of the governing compound and its synchronic reinterpretation as a derivative - a process that might have started off in ambiguous cases

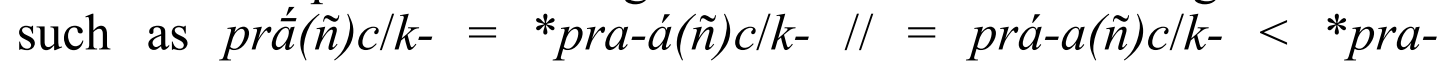
$H a ́(n) t / k$ -

\section{Excursus: The case of $\boldsymbol{k a n}_{i}$ yan-}

The noun kaniyan- 'a (young) girl' can on the evidence of the few residual forms such as Nsg. kaniyā, Asg. kanyánām $\leftarrow$ *kanyànam $<*$ kaniíanam and the weak stem kanìn- be securely said to have been mesocolumnar in (Early) Vedic. Given its etymological profile ${ }^{40}$, however, the expected AC should actually have surfaced as hysterodynamic: Nsg. *knni- $H_{3} \dot{e} n>* k a n i i-\bar{a}$, Asg. $* k n n i-H_{3} e ́ n-m$

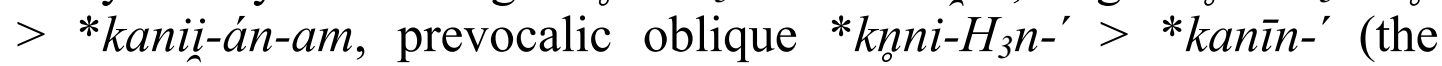
middle stem is unattested but would surely have been $* k n n i-H_{3} n-C^{\circ}$ $\left.>* k a n i i-a-C^{\circ}\right)$. But the source of the noun's obviously secondary accentual pattern is not difficult to find: the only actually attested pre-vocalic oblique in the extant corpus is the genitive plural kanínam, and it is exactly here (where due to the remodelling in the domain of the synchronically vocalic stems the synchronic rules of accent positioning were most fragile) that this unique and solitary representative of its inherited hysterodynamic paradigm with laryngeal-induced allomorphy must have first coalesced with the only other synchronic type available that exhibited the same peculiarity in exchanging prevocalic $*_{-i i}$ - for preconsonantal $*_{-} \bar{l}$-, so that it was the mesocolumnar feminine $\bar{l}$-stems that upon the coalescence of the genitival forms (*kaninăm $\rightarrow$ regularised to *kanínam, since both synchronically existing stems that at the same time also exhibited a preconsonantal $-\bar{l}$-, i.e., the mesocolumnar $=$

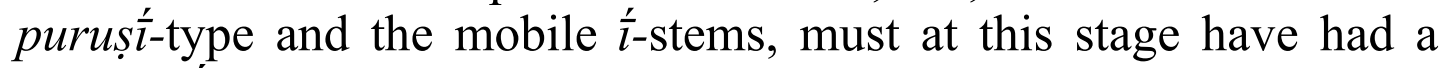
steady -ina $\bar{m}$ in the Gpl.) will have exerted the pressure towards regularising *kanii-án- to *kaníi-an- $=$ kaniyan- $^{-}$(purușínām : kanīnàm $=$ purușíi- $V^{\circ}: x=$ kaníi $^{\circ} V^{\circ}$ ) and then induce subsequent immobilisation of the weak stem also outside of the genitive plural, so that $*$ kanīn- $V^{\circ} \rightarrow$ kanīn- $V^{\circ}\left(\right.$ purușii $V^{\circ}:$ kaníi $^{\circ}=$ purușì $C^{\circ}: x$ $=>\operatorname{kaní} C^{\circ}$ ).

\footnotetext{
${ }^{40}$ See, e.g., Pinault 2000: 96ff. (with a different reconstruction as regards the first member).
} 


\section{References}

Dunkel, G. 2016. Proto-Indo-Iranian striH- and PIE *sor- 'female, woman'. In: Sahasram ati srajas. Indo-European and Indo-Iranian Studies in Honor of Stephanie W. Jamison. D. Gunkel, J. T. Katz, B. H. Vine, M. L. Weiss (eds.). Ann Arbor, New York: Beech Stave Press: 3645.

EWAia. = Mayrhofer, M. 1992-2001: Etymologisches Wörterbuch des Altindoarischen: I-III. Heidelberg: Universitätsverlag C. Winter.

Hintze, A. 1994: Der Zamyād-Yašt: Edition, Übersetzung, Kommentar. Wiesbaden: Dr. Ludwig Reichert Verlag.

Keydana, G. (fthc.): Accentual mobility in Vedic. To appear in: vácāmàsi miśrá̀ krnavāmahai. Akten der Arbeitstagung der Indogermanischen Gesellschaft vom 4. bis 7. Juni 2019 in Ljubljana. L. Repanšek, H. Bichlmeier, V. Sadovski (eds.). Hamburg: Baar Verlag.

Lubotsky, A. 1992. The Indo-Iranian laryngeal accent shift and its relative chronology. In: Rekonstruktion und relative Chronologie. Akten der VIII. Fachtagung der Indogermanischen Gesellschaft, Leiden, 31. August-4. September 1987. R. Beekes, A. Lubotsky, J. Weitenberg (eds.). Innsbruck: Institut für Sprachen und Literaturen der Universität Innsbruck, 261-269.

Lubotsky, A. 2012. The Vedic paradigm for 'water'. In: Multi nominis grammaticus: Studies in Classical and Indo-European linguistics in honor of Alan J. Nussbaum on the occasion of his sixty-fifth birthday. A. Cooper, J. Rau, M. L. Weiss (eds.). Ann Arbor, New York Beech Stave Press, 159-164.

Lühr, R. (ed.). 2008. Nominale Wortbildung des Indogermanischen in Grundzügen. Die Wortbildungsmuster ausgewählter indogermanischer Einzelsprachen. Band 2: Hethitisch, Altindisch, Altarmenisch (bearbeitet von Joachim Matzinger). Hamburg: Verlag Dr. Kovač.

Nielsen, B. 2004. An introduction to Vedic nominal accentuation (An attempt at a simplified analysis). In: Per aspera ad asteriscos. Studia indogermanica in honorem Jens Elmegård Rasmussen sexagenarii Idibus Martiis anno MMIV. A. Hyllested, A. R. Jørgensen / J. H. Larsson / Th. Olander (eds). Innsbruck: Institut für Sprachen und Literaturen der Universität Innsbruck, 379-396.

Nikolaev, A. 2009. The Germanic word for 'sword' and delocatival derivation in Proto-Indo-European. The Journal of Indo-European Studies 37, 462-488.

Peters, M. 1993: Ein weiterer Fall für das Rixsche Gesetz. In: Indogermanica et Italica. Festschrift für Helmut Rix zum 65. Geburtstag. G. Meiser (unter Mitarbeit von J. Bendahman, J. A. Hardarson und C. Schaefer) (eds.). Innsbruck: Institut für Sprachen und Literaturen der Universität Innsbruck, 373-405.

Pinault, G.-J. 2000: Védique dámūnas-, latin dominus et l'origine du suffixe de Hoffmann. Bulletin de la Société de linguistique de Paris 95/1, 61-118.

Repanšek, L. 2017: devā́śca và ásurāś cāspradhanta. Berilo vedske proze/A Vedic prose reader. Ljubljana: Znanstvena založba Filozofske fakultete. 
Repanšek, L. 2019: Notulae breves Indo-Iranologicae. Indoevropeiskoe yazykoznanie i klassicheskaya filologiya [Indo-European linguistics and classical philology] 23, 928-938.

RiVeLex = Krisch, Thomas (unter Mitarbeit von Ch. Katsikadeli, S. Niederreiter, K. Sampanis und S. Ziegler), 2012b: RIVELEX. Rigveda-Lexikon. Band 2. Wörter beginnend mit anderen Vokalen als , ,a“. Graz: Leykam Verlag.

Scarlata, S. 1999: Die Wurzelkomposita im Rg-Veda. Wiesbaden: Reichert Verlag.

Schindler, J. 1975: L'apophonie des themes indo-européens en $-r / n$. Bulletin de la Société de linguistique de Paris 70, 1-10.

Schneider, C. 2010. Die maskulinen Stämme auf -man- und -iman-im Altindischen. Wortbildung, Funktion und indogermanischen Grundlagen. Hamburg: Verlag Dr. Kovač.

Zair, N. 2011. PIE 'bird' and 'egg' after Schindler. Münchener Studien zur Sprachwissenschaft 65, 288-310.

Wackernagel, J., Debrunner, A. 1930: Altindische Grammatik. III. Band: Nominalflexion - Zahlwort - Pronomen. Göttingen: Vandenhoeck und Ruprecht.

Wackernagel, J., Debrunner, A. 1954: Altindische Grammatik. Band II,2: Die Nominalsuffixe. Göttingen: Vandenhoeck und Ruprecht. 